\title{
Anatomy of the Lymphatic Drainage of the Upper Limb and Breast and its Role in Lymphedema Prevention after Breast Cancer Treatment
}

\author{
Anatomía del Drenaje Linfático del Miembro Superior y de la Mama y su Papel \\ en la Prevención del Linfedema Después del Tratamiento del Cáncer de Mama
}

Cuadrado G. A.; Andrade M. F. C.; Akamatsu F. E. \& Jacomo A. L.

CUADRADO, G. A.; ANDRADE, M. F. C.; AKAMATSU, F. E. \& JACOMO, A. L. Anatomy of the lymphatic drainage of the upper limb and breast and its role in lymphedema prevention after breast cancer treatment. Int. J. Morphol., 34(3):1117-1122, 2016.

SUMMARY: The surgical treatment of breast cancer has been enhanced throughout the years in order to offer oncologically safer and more effective results with lower esthetic impact and fewer sequelae. The lymphedema of the upper limb is still an iatrogenic result of great incidence and morbidity after this treatment. A possible existence of independent breast and upper limb lymphatic pathways has become the issue of many researchers willing to minimize its occurrence. This review aims to compare the lymphatic pathways in the axilla described by traditional anatomy books and recently published articles about Axillary Reverse Mapping (ARM). With this purpose, a comparative table was made with the descriptions found in books and articles, a statistic table of the data collected, a flowchart of anastomoses among nodes and an analytical drawing of the most statistically mentioned drained areas. It was observed that there is great variability in the descriptions of drainage and anastomoses among the lymph nodes in the references used, so there should be a consensus of a universal description which also assembles possible anatomical variations. Furthermore, the findings brought about by recent studies show possible anastomoses among pathways and lymph nodes, however they have not been taken into consideration when ARM was initially proposed. Therefore, the axillary resection with the preservation of the posterior and lateral axillary lymph nodes is theoretically possible to avoid lymphedema of the upper limb, but the development of an updated universal description that involves all possible anatomical variations will provide a safer and more effective treatment.

KEY WORDS: Anatomy; Mapping; Axillary; Lymphatics; Upper Limb; Drainage; Breast.

\section{INTRODUCTION}

Breast cancer has one of the highest incidence rates among the different kinds of carcinomas is the world, accounting for 1,384 cases in a hundred thousand in the world (International Agency for Research on Cancer, 2010), and 49 cases in a hundred thousand only in Brazil. According to research, the lifetime risk of developing the invasive form of this disease is $12.15 \%$ or 1 in 8 women (American Cancer Society, Surveillance Research, 2011). The lymphedema occurs in $15 \%$ to $20 \%$ of patients who underwent breast cancer treatment and, even after the use of more conservative therapy, its incidence ranges from 6 $\%$ to $30 \%$ (Harris et al., 2002). Subsequently to the appearance of the Sentinel Lymph Node Biopsy (SLNB) technique, the total resection of axillary lymph nodes has become unnecessary as long as SLNB is negative; nonetheless, positive SLNB still demands extensive removal of axillary lymph nodes which, in addition to lymphatic radiotherapy, is associated to a $35 \%$ risk of lymphedema (Buchkolz et al., 2009).

The Axillary Reverse Mapping (ARM) is a technique which enables the intrasurgery distinction between upper limb and tumor region draining lymph nodes after using a special dye injection in the medial bicipital sulcus in order to mark the lymphatic vessels of the arm and their respective axillary nodes. This way, it is possible to visualize lymph nodes which have higher chances of being free of tumor cells since they drain mostly or exclusively the upper limb. Although it seems to be a promising technique, studies diverge in its therapeutic success and safety. 
This divergence is due to the still uncertain anatomy of the lymphatic drainage of the breast and upper limb, mostly based on very little updated studies and without the support and knowledge the recent techniques can bring about. The studies carried out by Sappey (1874) are still some of the few descriptions of the lymphatics even today. Thus a universal anatomical description and an analysis of all anatomical variations of the lymphatics are yet unavailable for clinical practice and, especially, for oncological surgery.

\section{MATERIAL AND METHOD}

We selected 14 traditional anatomy books, of which text-books and atlases were used for analyses. A detailed search was carried out for all descriptions of the anatomy of the upper limb and the breast lymphatic drainage in the axillary region. The obtained data was grouped and organized in table I, the lines represent the sources used and the columns display the group of lymph nodes. The lines were set in the alphabetical order according to the first author's last name and the columns were organized into intra-axillary lymph nodes, besides the surgical division into levels I, II and III in relation to pectoralis minor muscle; and into extra-axillary. As to evaluate the observed frequency of the descriptions in Table I, we prepared another Table II, the lines contain the drained areas and the columns contain the groups of nodes in the same organization used in Table I. The breast was divided into five regions for a better evaluation of tumor location and drainage: superolateral, superomedial, inferomedial, inferolateral and posterior part of the breast. The double columns were used to describe overall observed frequency in a whole region and the contribution of each quadrant to it. A schematic drawing (Fig.1) presents all observed frequency above 25 $\%$ obtained in Table II. Each circle has a distinct color representing a group of lymph nodes and their draining areas. The area where the circle is placed represents the drained area according to the data. The circles are placed at random in the anatomical area and mammary quadrants because the obtained descriptions are diffuse and nonspecific about the exact micro-region drained.

As to evaluate the anastomoses and flows among groups of lymph nodes proposed by the literature, a flowchart was elaborated (Fig.2). The circles represent groups of lymph nodes with their relative sizes and positions, out of scale. The circles and arrows are colored differently for legend identification specifying the source of the description. The numbers written inside some circles correspond to the number of lymph nodes present in the group. The legend has the origin of the data and a table to the left has the surgical division of the groups of lymph nodes in relation to the pectoralis minor muscle (Roberts, 2010; Standring, 2011).

\section{RESULTS}

The first conclusion obtained is the fact that most bibliography used in the medical education has very little information about lymphatic drainage and that most of this information is inconsistent if compared to other sources, hence, there should be an update and agreement among anatomists as to establish a unique drainage description.

The data obtained also gives theoretical support to preserve the posterior and lateral axillary lymph nodes even after positive SLNB as an alternative to avoid lymphedema of the upper limb. The infra-clavicular lymph nodes can possibly be preserved, yet the $16.7 \%$ chance of existing breast drainage to this group demands complementary studies for confirmation.

The flowchart illustrates there are collateral ways which enable the preserved lymph nodes to keep the lymphatic flow to the subclavian trunk even if levels II and III are removed. Jacomo (2009) also supports this idea by the description of 8 drainage currents from the proximal portion of the upper limb: basilic, cephalic, pre-bicipital, posteromedial, posterior, posterolateral, brachial and deep brachial; of which only 2 are derivative, do not direct to axillary nodes, the cephalic (supra-claviculary nodes) and the posterior (posterior scapulary nodes). This is why there is some drainage compensation after total axillary resection. Thus, the removal of highly suggestive metastatic groups when SLNB is positive can involve the resection of levels II and III, along with partial resection of level I, making use of ARM for identification of the lymph nodes for preservation.

Although ARM seems to be an interesting surgical possibility, Pavlista \& Eliska (2012a) problematizes the fact that there is presently no dye that can be used in surgery to establish the connections among lymph nodes, the dyes normally build up and do not follow through the anastomoses. So if there are anatomical variations which enable metastatic groups to communicate to the ARM lymph nodes, the patient will be exposed to high chances of disease progression due to medical error. Furthermore, currently, the injection of dye in the medial bicipital sulcus is the chosen site simply because of the rapid drainage in the spot (Lee $e t$ al., 2009). Notwithstanding, there are other drainage currents in the upper limb that do not pass by the site of injection, making the evaluation of ARM nodes still incomplete. 


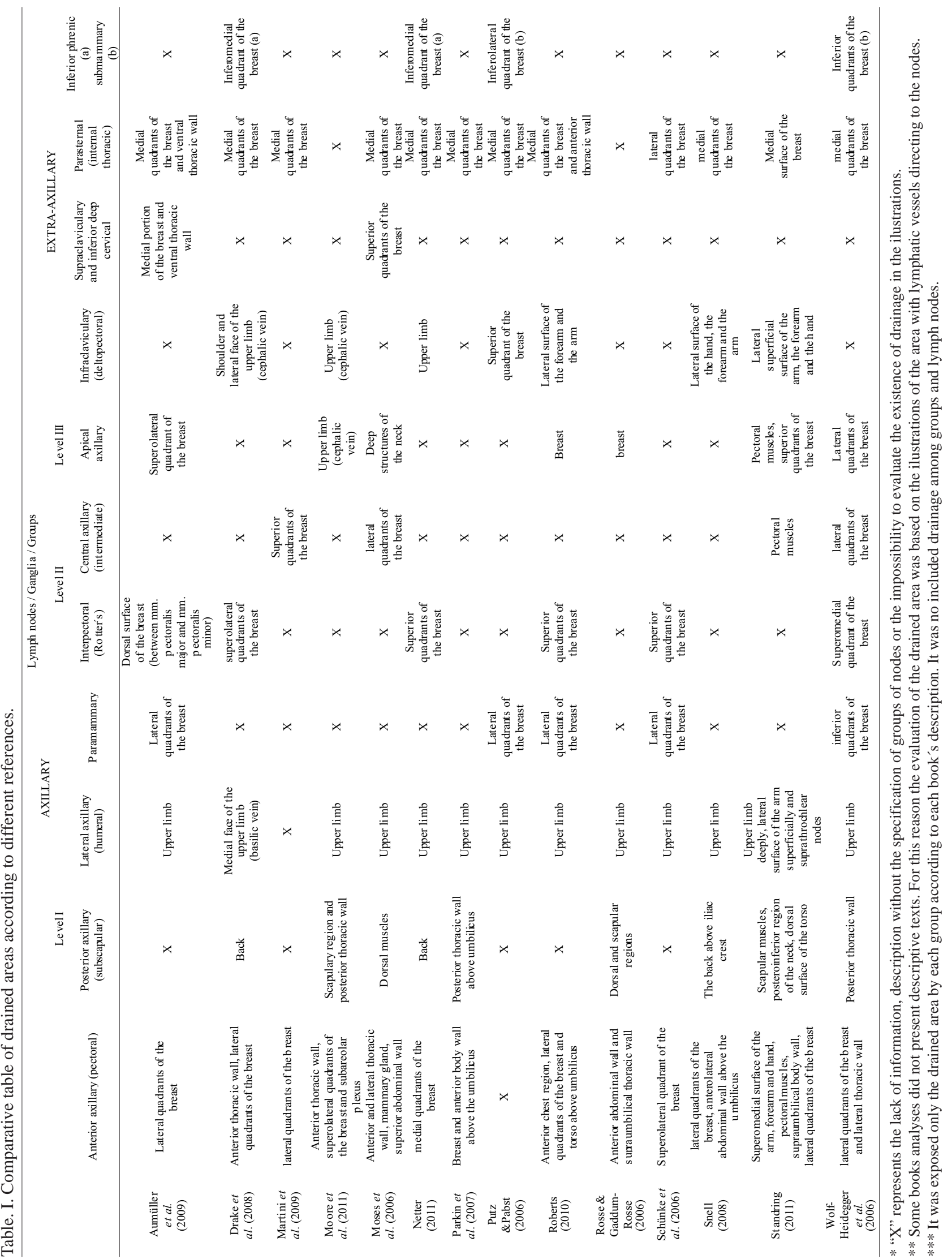



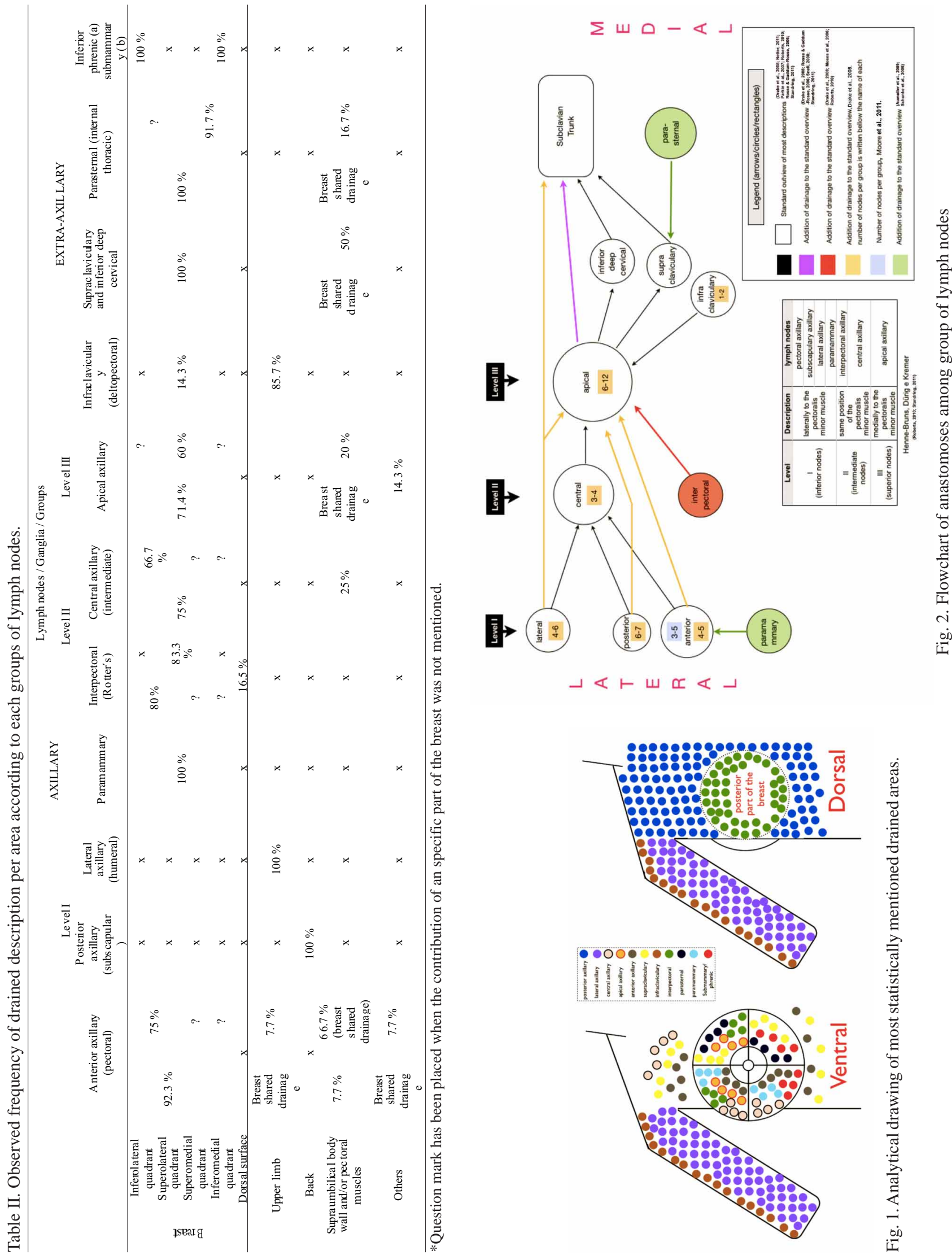


\section{DISCUSSION}

The possible shared drainage and anastomosis between breast and upper limb lymphatic ways has been tested by other authors. Some showed a positive view of the benefits and morbidity reduction by using this technique, even though further studies are necessary to affirm anything (Gobardhan et al., 2012) others defend the use of this technique in all cases, except in patients whose sentinel lymph node (SLN) is too close to the ARM lymph node and when there are too many compromised nodes (Boneti et al., 2009) and there are some who question the real effectiveness and therapeutic safety of this technique (Ikeda et al., 2012).

Another interesting point analyzed by Suami et al. (2008) is the fact that the lymphatic territory of the male and female torsos have differences in terms of the axillary lymph nodes which the lymphatic vessels direct to. This study also mentioned the existence of numerous anastomoses and shared lymph nodes between the torso and upper limb.

Ikeda et al. also limits the areas of ARM nodes, $88 \%$ of them, between the intercostobrachial nerve and axillary vein, frequently distant from the SLN. Pavlista \& Eliska (2012b) mention connections between ARM nodes and SLN in $24 \%$ of the cases, also with great location variation of ARM nodes. In other articles, Pavlista \& Eliska (2012b) also highlight that any change in axillary nodes generates the lymphedema due to the great number of anastomoses among groups of nodes, additionally, they point out that the maintenance of ARM nodes can be harmful in any case of positive SLNB because of a large net of anastomoses. Lee $e t$ al. also confirm the occurrence of all studied ARM nodes between the axillary vein and intercostobrachial nerve; however, they affirm the utility and safety of maintaining the ARM nodes is challenging, which leads to the conclusion that the drainage of the breast and the upper limb is probably similar.

Therefore, the creation of a complete lymphatic anatomic map with all possible variations would facilitate the location of ARM lymph nodes during surgery, in addition to the development of a dye which stains anastomoses among lymph nodes and a better understanding of the lymphatic drainage as well as possible shared drainage between the breast and the upper limb are essential to make the technique applicable and safe for clinical practice.

CUADRADO, G. A.; ANDRADE, M. F. C.; AKAMATSU, F. E. \& JACOMO, A. L. Anatomía del drenaje linfático del miembro superior y de la mama y su papel en la prevención del linfedema después del tratamiento del cáncer de mama. Int. J. Morphol., 34(3):1117$1122,2016$.

RESUMEN: El tratamiento quirúrgico del cáncer de mama ha mejorado a lo largo de los años con el fin de ofrecer resultados oncológicamente más seguros y eficaces con menor impacto estético y menos secuelas. El linfedema del miembro superior es todavía un resultado iatrogénico de gran incidencia y morbilidad después de este tratamiento. La posible existencia de vías linfáticas de mama y de los miembros superiores independientes se ha convertido en un tema central de muchas investigaciones para lograr minimizar su ocurrencia. Esta revisión tiene como objetivo comparar las vías linfáticas en la axila descritas en los libros de anatomía tradicionales con artículos recientemente publicados sobre Mapeo Reverso Axilar (MRA). Con este fin, se realizó un cuadro comparativo con las descripciones y un diagrama de flujo de las anastomosis entre los nodos, además de un dibujo analítico de las áreas drenadas estadísticamente más mencionadas. Se observó que existe una gran variabilidad en las descripciones sobre el drenaje y las anastomosis entre los nodos linfáticos, por lo que la descripción universal no debería ser considerada un consenso debido a que también presenta posibles variaciones anatómicas. Por otra parte, los resultados producidos por los estudios recientes muestran posibles anastomosis entre las vías y los nodos linfáticos, sin embargo, no se han tomado en consideración cuando se propuso inicialmente el MRA. Por lo tanto, la resección axilar con la preservación de la parte posterior y los nodos linfáticos axilares laterales es teóricamente posible para evitar el linfedema del miembro superior, pero el desarrollo de una descripción universal actualizada, que incluya todas las posibles variaciones anatómicas, proporcionará un tratamiento más seguro y eficaz.

PALABRAS CLAVE: Anatomía; Mapeo Axilar; Linfáticos; Miembro superior; Drenaje; Mama.

\section{REFERENCES}

Aumüller, G.; Aust, G.; Doll, A. \& Engele, J. Anatomia. Rio de Janeiro, Guanabara-Koogan, 2009. pp.280
Boneti, C.; Korourian, S.; Diaz, Z.; Santiago, C.; Mumford, S.; Adkins, L. \& Klimberg, V. S. Scientific Impact Award: Axillary 
reverse mapping (ARM) to identify and protect lymphatics draining the arm during axillary lymphadenectomy. Am. $J$. Surg., 198(4):482-7, 2009.

Buchholz, T. A.; Avritscher, R. \& Yu, T. K. Identifying the "sentinel lymph nodes" for arm drainage as a strategy for minimizing the lymphedema risk after breast cancer therapy. Breast Cancer Res. Treat., 116(3):539-41, 2009.

Drake, R. L.; Vogl, W. \& Mitchell, A. W. M. Gray's Atlas of Anatomy. Philadelphia, Churchill Livingstone/Elsevier, 2008.

Gobardhan, P. D.; Wijsman, J. H.; van Dalen, T.; Klompenhouwer, E. G.; van der Schelling, G. P.; Los, J.; Voogd, A. C. \& Luiten, E. J. ARM: axillary reverse mapping - the need for selection of patients. Eur. J. Surg. Oncol., 38(8):657-61, 2012.

Harris, J. R.; Lippman, M. E.; Morrow, M. \& Osborne, C. K. Doenças da Mama. Rio de Janeiro, Medsi, 2002.

Ikeda, K.; Ogawa, Y.; Komatsu, H.; Mori, Y.; Ishikawa, A.; Nakajima, T.; Oohira, G.; Tokunaga, S.; Fukushima, H. \& Inoue, T. Evaluation of the metastatic status of lymph nodes identified using axillary reverse mapping in breast cancer patients. World J. Surg. Oncol., 10:233, 2012.

International Agency for Research on Cancer (IARC). GLOBOCAN 2008: Cancer Incidence and Mortality Worldwide. Lyon, World Health Organization (WHO), 2010.

Jacomo, A. L. Anatomia do Sistema Linfático. In: Guedes Neto, H. I. B. \& Belczak, C. E. Q. Linfologia: Diagnóstico, Clínica e Tratamento. Sao Paulo, Yendis, 2009.

Lee, S. K.; Choi, J. H.; Lim, H. I.; Kim, W. W.; Kim, S.; Choe, J. H.; Lee, J. E.; Kim, J. H.; Kim, J. S.; Nam, S. J. \& Yang, J. H. Arm sentinel lymph node detection for preserving the arm lymphatic system. J. Breast Cancer, 12(4):272-7, 2009.

Martini, F.; Timmons, M. J. \& Tallitsch, R. B. Human Anatomy. San Francisco, Pearson Benjamin Cummings, 2009.

Moore, K. L.; Dalley, A. F. \& Agur, A. M. R. Anatomia Orientada para a Clínica. $6^{\mathrm{a}}$ ed. Rio de Janeiro, Guanabara Koogan, 2011.

Moses, K. P.; Banks, J. C.; Nava, P. B. \& Petersen, D. Atlas Fotográfico de Anatomia Clínica. $4^{\mathrm{a}}$ ed. Rio de Janeiro, Mosby/ Elsevier, 2006.

Netter, F. H. Atlas of Human Anatomy. 5th ed. Philadelphia, Saunders/Elsevier, 2011.

Parkin, I.; Logan, B. M. \& McCarthy, M. J. Core Anatomy Illustrated. Boca Raton, CRC Press, 2007.

Pavlista, D. \& Eliska, O. Analysis of direct oil contrast lymphography of upper limb lymphatics traversing the axilla a lesson from the past -- contribution to the concept of axillary reverse mapping. Eur. J. Surg. Oncol., 38(5):390-4, 2012.
Pavlista, D.; Eliska, O. Relationship between the lymphatic drainage of the breast and the upper extremity: a postmortem study. Ann. Surg. Oncol., 19(11):3410-5, 2012.

Putz, R. \& Pabst, R. (Eds.). Sobotta. Atlas de Anatomía Humana. Rio de Janeiro, Guanabara-Koogan, 2006.

Roberts, A. Livro Completo do Corpo Humano - Guia Visual Definitivo. São Paulo, Pearson, 2010.

Rosse, C. \& Gaddum-Rosse, P. Tratado de Anatomia de Hollinshead. Rio de Janeiro, Revinter, 2006.

Sappey, M. P. C. Anatomie, Physiologie, Pathologie des Vaisseaux Lymphatiques considérés chez L'homme et les Vertébrés. Paris, Adrien Dalahaye, 1874.

Schünke, M.; Schulte, E. \& Schumacher, U. Prometheus. Texto y Atlas de Anatomía. Buenos Aires, Editorial Médica Panamericana, 2006.

Snell, R. S. Clinical Anatomy by Regions. 8th ed. Philadelphia, Lippincott Williams \& Wilkins, 2008.

Standring, S. Anatomia Gray's A Base Anatômica da Prática Clínica. 40a ed. Sao Paulo, Elsevier, 2011.

Suami, H.; O’Neill, J. K.; Pan, W. R. \& Taylor, G. I. Superficial lymphatic system of the upper torso: preliminary radiographic results in human cadavers. Plast. Reconstr. Surg., 121(4):12319,2008

Wolf-Heidegger, G.; Kopf-Maier, P. \& Werneck, H. Atlas de Anatomia Humana: Anatomia Geral, Parede do Tronco e Membros. 6a ed. São Paulo, Guanabara Koogan, 2006. pp.768.

Corresponding to:

Guilherme de Arruda Cuadrado

Faculty of Medicine

University of São Paulo

São Paulo

BRAZIL

Email:guilhermedearruda@hotmail.com

Received: 03-11-2015

Accepted: 07-07-2016 